\title{
3D CT Soft Tissue Craniofacial Analysis and Lip Morphology
}

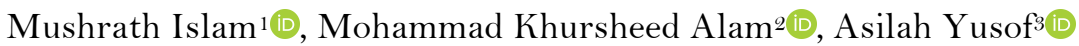

${ }^{1}$ Orthodontic Unit, School of Dental Science, Universiti Sains Malaysia, Kelantan, Malaysia.

2Orthodontic Department, College of Dentistry, Jouf University, Sakaka, Kingdom of Saudi Arabia.

${ }^{3}$ Craniofacial Morphology Unit, School of Dental Science, Universiti Sains Malaysia, Kelantan, Malaysia.

Correspondence: Dr. Mohammad Khursheed Alam, Orthodontic Department, College of Dentistry, Jouf University, Sakaka, Kingdom of Saudi Arabia. E-mail: dralam@gmail.com

Academic Editor: Yuri Wanderley Cavalcanti

Received: 24 April 2020 / Review: 24 August 2020 / Accepted: 09 October 2020

How to cite: Islam M, Alam MK, Yusof A. 3D CT soft tissue craniofacial analysis and lip morphology. Pesqui Bras Odontopediatria Clín Integr. 202 1; 21:e0077. https://doi.org/10.1590/pboci.202 1.036

\begin{abstract}
Objective: To assess the soft tissue characteristics of Bangladeshi adults to formulate soft tissue $3 \mathrm{D}$ CT standards using Holdaway's (HA) and lip morphology (LM) analyses. Another aim of this study was to assess the gender dimorphism of Bangladeshi population. Material and Methods: One hundred and seventeen (Eighty-five men and Thirty-two women) Bangladeshi adults have obtained their computed tomography (CT) scan at the Radiology Department for normal diagnosis. Craniofacial deformities were undetected in all cases. The CT images were prepared by a $3 \mathrm{D}$ imaging programming software (Mimics 11.02 Materialise). Parameters from the identified landmark points were measured in 3D through this software. Results: Upper lip thickness (ULT) (vermillion UL-A point) measurement was significant in HA and in LM analyses, upper lip protrusion (ULP) (Ls to Sn-SPog) measurement has demonstrated significant difference among both genders, where p-value was less than 0.05. Mean measurements of Bangladeshi adults were relatively comparable except the face convexity (FC) when compared with the HA cephalometric soft tissue values. Conclusion: By using HA and LM analyses, 3D CT soft tissue standards were established for Bangladeshi adults. Measurements for all parameters have remained equivalent with the HA standard data apart from the FC measurement. This consequently may demonstrate that the Bangladeshi population retains a convex shape with a slight protrusive lip or retruded chin.
\end{abstract}

Keywords: Diagnostic Imaging; Tomography, X-Ray Computed; Orthodontics. 


\section{Introduction}

Mental prosperity, Social acknowledgement, and individual confidence are connected with physical appearance [1]. Therefore, appearance is one of the essential elements of the face. Somewhere in the range of 5000 years back, the antiquated Egyptians stated their attention towards beauty and aesthetics [2]. Asymmetrical human faces are not beautiful, though balanced facial appearance remains satisfactory unless constantly delightful [3]. For an individual, some components (age, culture, ethnic background and personality) may influence the meaning of an appealing and satisfying look [4]. Achieving utmost facial aesthetic is the supreme objective for orthodontic and maxillofacial specialists [5].

In the human body, the face is considered the most variable part. Variability is specified by the facial size and shape of an individual and significantly added by the relation of these facial profiles to one another. Facial quantities like harmony and disparity must be determined quantitatively but sadly only described in words earlier [6]. By orthodontic analysis and treatment planning, the significance of soft tissue esthetics has been described by different investigators. Many studies showed that soft tissues that vary significantly in thickness remain the key consideration in deciding a subject's ultimate facial profile [7-9]. Therefore, solitary investigation of dental and skeletal forms might be insufficient, as different varieties of the soft tissues involved in the dento-skeletal structure. Since treatment procedures turn out to be more powerful, additional importance has been given on the soft tissues.

For lip posture assessment and the profile's aesthetic quality, few line analyses have been proposed [10]. Rickett's "E" line [11] is affected a lot through the development of the nose. Steiner's "S" line [12] disposes of a larger change in skin profile because of the development of the nose, though HA "H" line [8] gets the benefit of eliminating the impact of nasal development in the assessment of lip posture.

After the revelation of cephalometric in 1931, it has been popular as a fundamental clinical instrument for the assessment of dento-skeletal relationship in orthodontics [13]. Disappointingly, information acquired from the cephalometric radiographs has been related with few faults like geometric distortion and superimposition of structures on the radiographs [14]. Currently, three-dimensional (3D) imaging techniques, for example, cone-beam computed tomography (CBCT) and computed tomography (CT), have played a vital part in the dental field. Through these modalities, the orthodontists can imagine 3D pictures of craniofacial structures without including the superimposition of anatomical structures [15]. With various 3D imaging programming methods, $2 \mathrm{D}$ pictures can reproduce in $3 \mathrm{D}$. These reproduced images can offer correct and precise information to study a basic craniofacial problem [16].

Ethnic groups, sex, race, age, and so forth impact on normal esthetical qualities of the face [17]. A few studies have been completed to examine the differences in the essences of different racial groups together with Caucasian [18], Chinese [19], Japanese [20], Korean [21], Saudi [22], Malaysian Chinese [23], Malaysian Malay [24], Malaysian Indian [25], Indian [26], Pakistani [27] and Bangladeshi [28,29]. However, all these studies were carried out in cephalometry.

\section{Material and Methods}

Subjects and Samples

This cross-sectional retrospective study included one hundred and seventeen Bangladeshi patients who performed their CT scans at the Radiology Department of Medinova Medical Services LTD. Patients 
performed their CT scans for reasons other than craniofacial difficulties (for example, migraines, serious cerebral pain, changes in mental status). The inclusion criteria for this study were age eighteen to sixty-five years, no history of plastic or reconstructive medical method and excellent quality CT volumetric data. Subjects with craniofacial deformities, wounds, burns or scar tissues, cleft lip, cleft palate in the craniofacial zone, also patients with a history of orthodontic treatment were excluded from this study.

Written Informed consent was taken from each patient before having a scan and all consent forms were reviewed and permitted by the institution's ethical authority. Data were collected from the archive with the best possible consent from the authority for study uses. All research-related task in this study was executed in the School of Dental Science, Hospital Universiti Sains Malaysia (HUSM). Approval for this study (USM/JEPeM/16080251) was gained from the Human Research and Ethics Committee of the Universiti Sains Malaysia.

PS Software version 3.0.43 was used regarding calculation of the sample size for male and female patients, with power $=80$ percent, alpha $=0.05$, mean difference $=2 \mathrm{~mm}$, ratio $=1: 2.5$ and measured standard deviation $=4.81 \mathrm{~mm}[30]$. Thirty-two female subjects and eighty-five male subjects were calculated in the sample size. Subjects were chosen based on the inclusion and exclusion criteria from a group of one hundred and sixty head \& neck CT scans. By using a simple random sampling technique (lottery method), final CT scans were selected.

Image Acquisition, Processing and Measurement Parameters

CT scans were gathered from the CT record archive between 2015 and 2016. These images were high-resolution helical scans acquired through the General Electric Light Speed Plus Discovery VCT 128 slice CT Scanner Method (GE Healthcare, Milwaukee, WI, USA) utilizing standard techniques. The CT resolution was fixed at a thickness of $1.25 \mathrm{~mm}$ and spacing of $1.25 \mathrm{~mm}$. The tube voltage and current existed $120 \mathrm{KV}$ and $150 \mathrm{~mA}$, individually. This could be balanced further as desired to modify the patient's weight.

CT scans were kept in Digital Imaging and Communications in Medicine (DICOM) format, stored in a personal computer and then introduced into the Mimics medical imaging software (version 11.02, Materialise, Leuven, Belgium). This software was also utilized to build three-dimensional (3D) images originated from two-dimensional (2D) cross-sectional images. A sequence of processes were performed on the CT data, for instance, thresholding, region growing, and editing.

3D image-segmentation utilizing Mimics software was availed to measure the parameters from the identified landmark points (Tables 1 and 2). First, CT data segmentation was performed to measure a region of interest for example, the outer craniofacial part or the inner part of the skull. CT images were converted to a "Mask" by means of a threshold technique in which a line on a $2 \mathrm{D}$ image (drawn using the "Profile Line" feature) acknowledged the particular threshold values that fluctuates within the line. In a 3D-CT reconstruction, the threshold level was used to decide the minimum density of material. This image was reformatted at a threshold value that separated soft tissue from bone and air. Region growing was performed to select simply the region of interest. The rest of the parts that shared the similar value of "mask" could be eliminated easily by utilizing the region growing technique to assure that the particular portion only was selected. Consequently, the $2 \mathrm{D}$ images were transformed into $3 \mathrm{D}$ images using the calculated $3 \mathrm{D}$ tool. Measurements were done on the $3 \mathrm{D}$ images with help of other $2 \mathrm{D}$ views. 
Table 1. Identified soft-tissue craniofacial landmarks and their definitions.

\begin{tabular}{|c|c|c|}
\hline Landmark & Name & Definition \\
\hline $\mathrm{SNa}$ & Soft Tissue Nasion & $\begin{array}{l}\text { The deepest point of the concavity between the forehead and soft tissue } \\
\text { contour of the nose. }\end{array}$ \\
\hline Point A & A Point & $\begin{array}{l}\text { Deepest bony point on the contour of the premaxilla below anterior nasal } \\
\text { spine. }\end{array}$ \\
\hline Point B & B Point & Deepest bony point on the contour of the mandible above the pogonion. \\
\hline SPog & Soft Tissue Pogonion & $\begin{array}{l}\text { The most prominent point on the soft tissue contour of the chin in the } \\
\text { midsagittal plane. }\end{array}$ \\
\hline Pog & Pogonion & The most anterior point of the convexity of the chin. \\
\hline Sn & Subnasale & $\begin{array}{l}\text { The junction between the lower border of the nasal septum, the partition } \\
\text { that divides the nostrils, and the cutaneous portion of the upper lip in the } \\
\text { midline. }\end{array}$ \\
\hline Prn & Pronasale & The most protruded point of the nasal tip. \\
\hline $\mathrm{Cm}$ & Collumela & The most antero-interior point of the soft tissue nose profile. \\
\hline Vermillion UL & Vermillion Upper Lip & $\begin{array}{l}\text { Height of the vermilion of the upper lip in the midline more than } 2 \mathrm{SD} \\
\text { above the mean. }\end{array}$ \\
\hline $\mathrm{S} 1$ & Sublabiale & The midpoint of the labiomental sulcus. \\
\hline Vermillion LL & Vermillion Lower Lip & $\begin{array}{l}\text { Height of the vermilion of the lower lip in the midline more than } 2 \text { SD } \\
\text { above the mean. }\end{array}$ \\
\hline $\mathrm{U}_{1} \mathrm{P}$ & Upper Incisor Apex & Apex of upper incisor. \\
\hline Ls & Labiale Superius & The midpoint of the vermilion border of the upper lip. \\
\hline $\mathrm{Li}$ & Labiale Inferius & The midpoint of the vermilion border of the lower lip to sublabiale. \\
\hline H line & Harmony Line & Tangent to the chin point to upper lip. \\
\hline S line & Facial Contour Line & $\begin{array}{l}\text { A line is drawn on the soft tissue contour of the chin to the middle of the } \\
\text { ' } \mathrm{S} \text { ' formed by lower border of the nose. }\end{array}$ \\
\hline E line & Esthetic Plane & A line extends from the tip of the nose to the chin. \\
\hline $\mathrm{FH}$ & $\begin{array}{l}\text { Frankfurt Horizontal } \\
\text { Plane }\end{array}$ & $\begin{array}{l}\text { This plane connects the lowest point of the orbit (orbitale) and the } \\
\text { superior point of the external auditory meatus (porion). }\end{array}$ \\
\hline
\end{tabular}

Table 2. Soft tissue craniofacial measurements using Holdaway's and lip morphology analyses.

\begin{tabular}{|c|c|}
\hline Variables & Measurements \\
\hline S-SNa line $(\mathrm{mm})$ & A line connecting sella to nasion \\
\hline Vermilion border UL-Prn (mm) & Nose prominence \\
\hline SPog-Pog $(\mathrm{mm})$ & Chin thickness \\
\hline Vermillion UL-FH (mm) & Superior sulcus depth \\
\hline Sn-H line $(\mathrm{mm})$ & Sub H line \\
\hline Vermillion UL-A point (mm) & Upper lip thickness \\
\hline LL-H line $(\mathrm{mm})$ & Lower lip to H line \\
\hline $\mathrm{SNa}-\mathrm{SPog}(\mathrm{mm})$ & Facial Plane (FP) \\
\hline $\mathrm{N}-\mathrm{SNa} / \mathrm{FH}\left(^{\circ}\right)$ & Soft-tissue facial angle \\
\hline $\mathrm{H}$ line $-\mathrm{FP}\left({ }^{\circ}\right)$ & $\mathrm{H}$ angle \\
\hline $\mathrm{N}-\mathrm{A}-\mathrm{Pog}\left(\left(^{\circ}\right)\right.$ & Convexity \\
\hline Ls to $\mathrm{E}$ line $(\mathrm{mm})$ & Upper lip to E line \\
\hline Li to $\mathrm{E}$ line $(\mathrm{mm})$ & Lower lip to E line \\
\hline Ls to $\mathrm{Sn}-\mathrm{SPog}(\mathrm{mm})$ & Protrusion of the upper lip relative to the lower face \\
\hline Li to Sn-SPog (mm) & Protrusion of lower lip relative to the lower face \\
\hline $\mathrm{Cm}-\mathrm{Sn}-\mathrm{Ls}\left({ }^{\circ}\right)$ & Nasolabial angle \\
\hline Ls-Sn-SPog $\left(^{\circ}\right)$ & Upper lip protrusion angle \\
\hline L1-PointB-SPog $\left(^{\circ}\right)$ & Inter labial sulcus angle \\
\hline L1-Sn-SPog $\left(^{\circ}\right)$ & Lower lip protrusion angle \\
\hline
\end{tabular}

Total measurements were performed by a solo researcher in an ideal manner (Figure 1 and 2). All measurements were remade three times. After two weeks, the second measurements were carried out and the researcher was blinded to the results to control bias. For the third time, the similar blinding was done, which is two weeks after the second measurement. The averages of the three readings of each measurement were considered for statistical analysis with the particular end goal of controlling intra-examiner variation. 


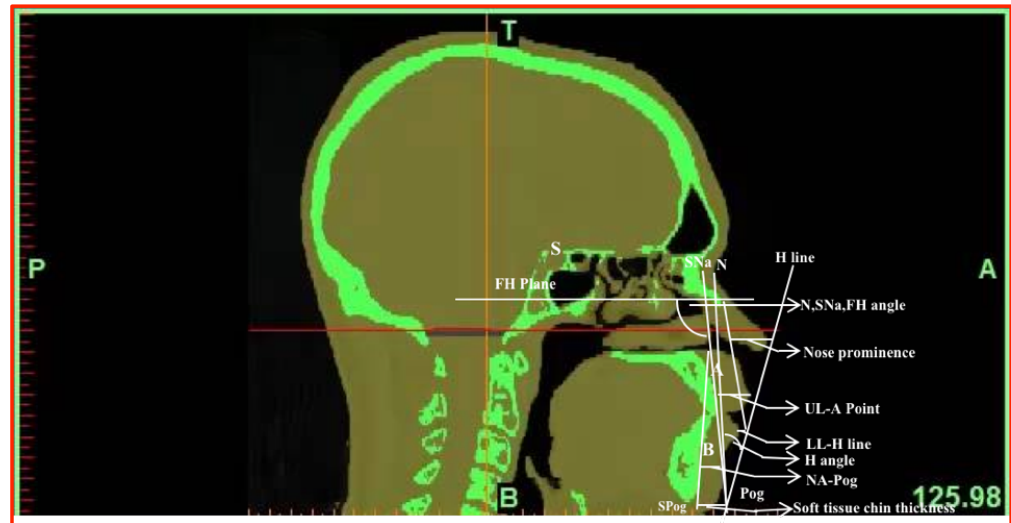

Figure 1. Performed soft-tissue craniofacial measurements for Holdaway's analysis.

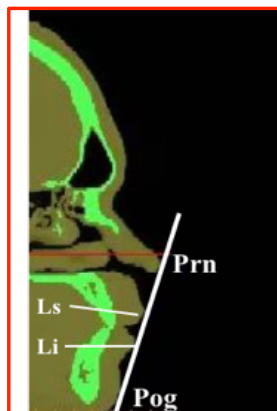

a and $b$

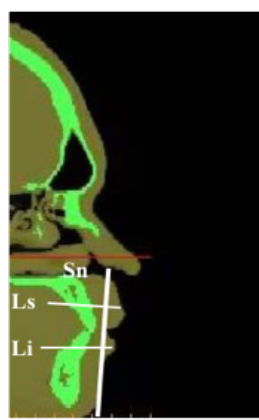

e and $\mathbf{f}$
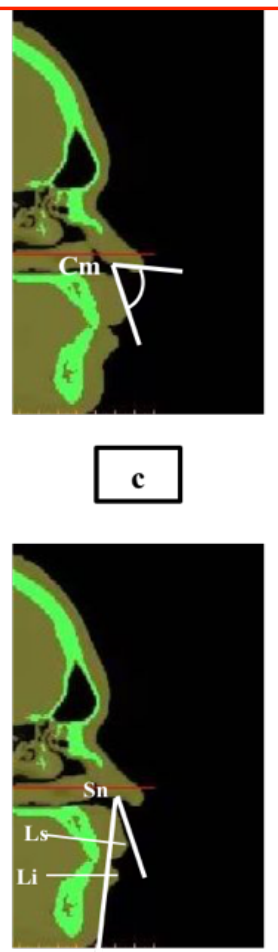

g
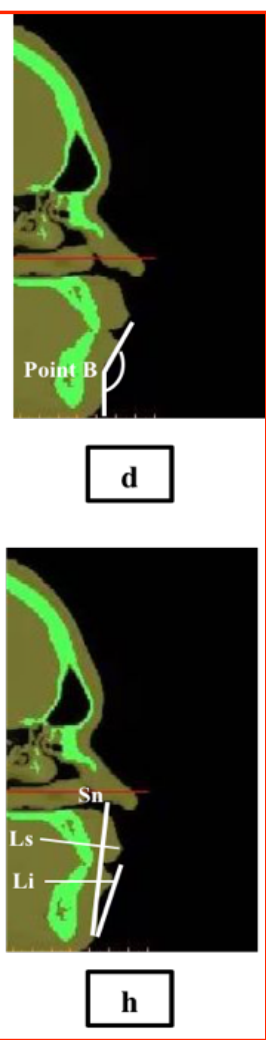

Figure 2. Performed soft-tissue craniofacial measurements for lip morphology analysis: a. Upper lip to E line (Ls to E line); b. Lower lip to E line (Li to E line). c. Nasolabial angle (Cm-Sn-Ls); d. Inter labial sulcus angle (L1-PointB-SPog); e. Upper lip protrusion (Ls to Sn-SPog); f. Lower lip protrusion (Li to Sn-SPog); g. Upper lip protrusion angle (Ls-Sn-SPog); h. Lower lip protrusion angle (L1-Sn-SPog).

Statistical Analysis

Data collected were initially documented in Excel (Version 14.0, Microsoft Corp., Redmond, WA, USA). Statistical analyses were achieved utilizing Statistical Package for the Social Sciences (SPSS) software (version 22.0, IBM, Armonk, NY, USA). Descriptive statistics like mean values (mean), standard deviations (SD), standard errors (SE) and coefficients of variation (CI) were produced independently for males and females. Normality of the data was analyzed through the Kolmogorov-Smirnov test. An independent-samples t-test was utilized to compare the mean measurements among men and women and p-values under 0.05 were recognized to be statistically significant. 


\section{Results}

The Kolmogorov-Smirnov test indicated that all data were generally distributed. Intraclass coefficient analyses revealed intra-examiner reliability values of 0.90-0.96. This demonstrated that the examiner was dependable in conducting the measurement. The study sample included eighty-five males and thirty-two females.

The soft tissue measurements, as well as normal values, were presented via HA and LM analyses in Tables 3 and 4. In HA analysis, only the ULT measurement (vermillion UL-A point) revealed a significant difference among male and female subjects $(\mathrm{p}<0.05)$. Total measurements revealed little variations apart from the $\mathrm{N}-\mathrm{SNa} / \mathrm{FH}$ angle, where the mean measurement was $88.89^{\circ}$ in males and $87.78^{\circ}$ in females. Only the face convexity (FC) (N-A-Pog) (3.62 $2^{\circ}$ in males and $3.66^{\circ}$ in females) has remained outside the established HA range. However, other measurements have remained within the established HA values.

In LM analysis, merely ULP measurement (Ls to Sn-SPog) has showed a significant variance among male and female subjects. All measurements were related with little variation. Li-E line (-0.27 mm in females and $-0.24 \mathrm{~mm}$ in males) has revealed negative values, which indicated that they were located in front of the $\mathrm{E}$ line.

Table 3. Comparisons of Holdaway's analysis between male and female subjects.

\begin{tabular}{|c|c|c|c|c|c|c|c|}
\hline \multirow[t]{2}{*}{ Variables } & \multirow[t]{2}{*}{ Gender } & \multirow[t]{2}{*}{ Mean } & \multirow[t]{2}{*}{ SD } & \multicolumn{2}{|c|}{$95 \% \mathrm{CI}$} & \multirow[b]{2}{*}{ p-value } & \multirow{2}{*}{$\begin{array}{c}\text { Holdaway's } \\
\text { Established } \\
\text { Value }\end{array}$} \\
\hline & & & & Lower & Upper & & \\
\hline \multirow[t]{2}{*}{ Vermillion UL-Prn (mm) } & Male & 17.89 & 0.925 & -0.402 & 0.419 & \multirow[t]{2}{*}{0.967} & \multirow[t]{2}{*}{$14-24$} \\
\hline & Female & 17.88 & 1.177 & -0.457 & 0.474 & & \\
\hline \multirow[t]{2}{*}{ SPog-Pog (mm) } & Male & 11.81 & 0.937 & -0.247 & 0.534 & \multirow[t]{2}{*}{0.468} & \multirow[t]{2}{*}{$10-12$} \\
\hline & Female & 11.67 & 0.988 & -0.262 & 0.549 & & \\
\hline \multirow[t]{2}{*}{ Vermillion UL-FH (mm) } & Male & 2.37 & 0.236 & -0.078 & 0.107 & \multirow[t]{2}{*}{0.757} & \multirow[t]{2}{*}{$1-4$} \\
\hline & Female & 2.35 & 0.195 & -0.071 & 0.100 & & \\
\hline \multirow[t]{2}{*}{ Sn-H line $(\mathrm{mm})$} & Male & 4.45 & 0.205 & -0.074 & 0.090 & \multirow[t]{2}{*}{0.849} & \multirow[t]{2}{*}{$5 \pm 2$} \\
\hline & Female & 4.45 & 0.184 & -0.071 & 0.087 & & \\
\hline \multirow{2}{*}{ Vermillion UL-A point (mm) } & Male & 15.27 & 0.572 & 0.158 & 0.665 & \multirow[t]{2}{*}{$0.002 *$} & \multirow[t]{2}{*}{15} \\
\hline & Female & 14.86 & 0.762 & 0.124 & 0.698 & & \\
\hline \multirow[t]{2}{*}{ LL-H line (mm) } & Male & 0.62 & 0.032 & -0.015 & 0.012 & \multirow[t]{2}{*}{0.776} & \multirow[t]{2}{*}{$0-0.5$} \\
\hline & Female & 0.63 & 0.034 & -0.016 & 0.012 & & \\
\hline \multirow[t]{2}{*}{ N-A-Pog $\left(^{O}\right)$} & Male & 3.62 & 0.285 & -0.161 & 0.075 & \multirow[t]{2}{*}{0.474} & \multirow[t]{2}{*}{$0.00^{\mathrm{O}}$} \\
\hline & Female & 3.66 & 0.298 & -0.165 & 0.079 & & \\
\hline \multirow[t]{2}{*}{$\mathrm{N}-\mathrm{SNa} / \mathrm{FH}\left({ }^{\mathrm{O}}\right)$} & Male & 88.89 & 5.004 & -0.964 & 3.177 & \multirow[t]{2}{*}{0.292} & \multirow[t]{2}{*}{$91^{\mathrm{O}} \pm 7^{\mathrm{O}}$} \\
\hline & Female & 87.78 & 5.132 & -1.012 & 3.226 & & \\
\hline \multirow[t]{2}{*}{$\mathrm{H}$ line $-\mathrm{FP}(\mathrm{O})$} & Male & 14.51 & 1.823 & -1.075 & 0.354 & \multirow[t]{2}{*}{0.319} & \multirow[t]{2}{*}{$7^{\mathrm{O}}-15^{\mathrm{O}}$} \\
\hline & Female & 14.87 & 1.490 & -1.018 & 0.296 & & \\
\hline
\end{tabular}

$\mathrm{CI}=$ Confidence Interval, $*$ Significant at $\mathrm{p}<0.05$.

Table 4. Comparisons of LMA between male and female subjects.

\begin{tabular}{|c|c|c|c|c|c|c|}
\hline \multirow[t]{2}{*}{ Variables } & \multirow[t]{2}{*}{ Gender } & \multirow[t]{2}{*}{ Mean } & \multirow[t]{2}{*}{ SD } & \multicolumn{2}{|c|}{$95 \%$ CI } & \multirow[t]{2}{*}{ p-value } \\
\hline & & & & Lower & Upper & \\
\hline \multirow[t]{2}{*}{ Ls to $\mathrm{E}$ line $(\mathrm{mm})$} & Male & 2.35 & 0.285 & -0.074 & 0.173 & 0.430 \\
\hline & Female & 2.30 & 0.342 & -0.087 & 0.186 & \\
\hline \multirow[t]{2}{*}{ Li to $\mathrm{E}$ line (mm) } & Male & -0.24 & 0.077 & -0.004 & 0.065 & 0.085 \\
\hline & Female & -0.27 & 0.101 & -0.009 & 0.070 & \\
\hline \multirow[t]{2}{*}{ Ls to $\mathrm{Sn}-\mathrm{SPog}(\mathrm{mm})$} & Male & 5.22 & 0.398 & -0.001 & 0.321 & $0.042 *$ \\
\hline & Female & 5.06 & 0.364 & -0.006 & 0.316 & \\
\hline \multirow[t]{2}{*}{ Li to $\mathrm{Sn}-\mathrm{SPog}(\mathrm{mm})$} & Male & 4.33 & 0.436 & -0.162 & 0.211 & 0.793 \\
\hline & Female & 4.31 & 0.498 & -0.176 & 0.225 & \\
\hline
\end{tabular}




\begin{tabular}{|c|c|c|c|c|c|c|}
\hline \multirow[t]{2}{*}{$\mathrm{Cm}-\mathrm{Sn}-\mathrm{Ls}\left({ }^{\circ}\right)$} & Male & 103.16 & 0.907 & -0.316 & 0.411 & \multirow[t]{2}{*}{0.796} \\
\hline & Female & 103.12 & 0.816 & -0.302 & 0.397 & \\
\hline \multirow[t]{2}{*}{ L1-Point B-SPog $\left(^{\circ}\right)$} & Male & 133.22 & 1.778 & -0.179 & 1.322 & \multirow[t]{2}{*}{0.134} \\
\hline & Female & 132.65 & 1.954 & -0.222 & 1.366 & \\
\hline \multirow[t]{2}{*}{ Ls-Sn-SPog $\left(^{\circ}\right)$} & Male & 8.76 & 0.933 & -0.387 & 0.353 & \multirow[t]{2}{*}{0.928} \\
\hline & Female & 8.77 & 0.808 & -0.366 & 0.333 & \\
\hline
\end{tabular}

$\overline{\mathrm{CI}}=$ Confidence Interval, ${ }^{*}=$ Significant at $\mathrm{p}<0.05$.

Table 5 presents the HA analysis. The face convexity of all populations was appeared to be higher than the HA established value. Table 6 shows the LM measures for different populations.

Table 5. Comparisons between Bangladeshi and other populations for Holdaway's analysis.

\begin{tabular}{lccccc}
\hline \multicolumn{1}{c}{ Variables } & $\begin{array}{c}(3 \mathbf{B D T}) \\
\text { Present Study }\end{array}$ & Saudi & Japan & Chinese & Palestinian \\
\hline N-A-Pog & 3.62 & 1.75 & 2.42 & 1.5 & 1.76 \\
N-SNa/FH & 88.89 & 89.66 & 90.16 & 92.5 & 92.23 \\
vermillion UL-Prn & 17.89 & 12.36 & 14.54 & 6 & 18.33 \\
Spog-Pog & 11.81 & 11.33 & 13.58 & 9 & 12 \\
vermillion UL-FH & 2.37 & 2.92 & 4.46 & 9 & 3 \\
Sn-Hline & 4.45 & 5.03 & 9.06 & 4 & 4.7 \\
Vermillion UL-Apoint & 15.27 & 15.69 & 15.11 & 15 & 12.33 \\
H line -FP & 15.51 & 15.16 & 15.51 & 16 & 14.21 \\
LL-H line & 0.62 & 0.86 & 1.62 & 0.5 & 1.62 \\
\multicolumn{1}{c}{ No. Subject } & 117 & 61 & 211 & 48 & 93 \\
\hline
\end{tabular}

Table 6. Comparisons between Bangladeshi and other populations for lip morphology analysis.

\begin{tabular}{lcccccc} 
Variables & $\begin{array}{c}\text { 3DCT } \\
\text { Present } \\
\text { Study }\end{array}$ & $\begin{array}{c}\text { Malaysian } \\
\text { Chinese }\end{array}$ & Nigerian & $\begin{array}{c}\text { Cephalometry } \\
\text { Malaysian } \\
\text { Malay }\end{array}$ & North Indian & Pakistani \\
\hline Ls to E line & 2.35 & -1.03 & 4.07 & -0.015 & $*$ & 1.38 \\
Li to E line & -0.24 & 0.92 & 7.88 & 0.459 & $*$ & -0.715 \\
Cm-Sn-Ls & 103.16 & 99.66 & $*$ & 84.893 & 112.14 & 102.7 \\
Point B & 133.22 & 144.48 & $*$ & 124.325 & 128.8 & 104.1 \\
Ls to Sn-Pog & 5.22 & $*$ & 6.77 & 1.249 & 2.59 & 4.552 \\
Sn-Pog to Ls & 8.76 & $*$ & 9.84 & 26.25 & $*$ & 29.36 \\
Li-Sn-Pog & 4.33 & $*$ & 9.02 & 1.678 & 1.99 & 3.47 \\
Sn-Pog-Li & 6.9 & $*$ & 10.53 & 13.368 & $*$ & 11.42 \\
No. Subject & 117 & 98 & 100 & 70 & 100 & 100 \\
\hline
\end{tabular}

\section{Discussion}

The achievement of orthodontic treatment is mostly acknowledged by the variation picked up in the patient's facial look, which includes the soft tissue profile. In HA investigation [8,9], Frankfort horizontal (FH) plane was used as a basis of the perspective plane.

In this study, the correlations of the Bangladeshi genders were achieved by using the means and SD of the values. The soft tissue facial angle (STFA) and convexity angle (CA) were used to overview the concavity or convexity of the profile. In this study, the STFA was $88.89^{\circ}$ in males, $87.78^{\circ}$ in females and the CA was $3.62^{\circ}$ in males, $3.66^{\circ}$ in females, which demonstrated a tendency to straight profile steady with Class I classification.

Measurements of HA soft tissue of Bangladeshi subjects were compared with the HA cephalometric established soft tissue values [8,9]. Bangladeshi population carries a convex profile because FC has remained outside the normal established HA range in this population. The $\mathrm{H}$ angle for the current population was bigger 
when compared with the HA established value. The increased $\mathrm{H}$ angle may indicate ULP or retrusion of the chin (RC). However, rest of measurements have remained within the established HA values.

For HA analysis, the present data were compared with the Saudis [31], Japanese [20], Chinese [19] and Palestinians [32] (Table 5). The FC of all populations was appeared to be higher than the HA established value. STFA in all populations was appeared to be within the HA established value. The nose prominence (NP) in the current study $(17.89 \mathrm{~mm})$, the Japanese [20] $(14.54 \mathrm{~mm})$ and the Palestinians [32] $(18.33 \mathrm{~mm})$ were steady with the HA established value. Nevertheless, the Saudis [31] (12.36 mm) and the Chinese [19] (6 mm) were exhibited to have less NP. The soft tissue chin thickness (STCT) in the Bangladeshis (11.81 mm), the Saudis [31] (11.33 mm) along the Palestinians [32] (12 mm) were within the HA established value. However, the Japanese [20] $(13.58 \mathrm{~mm})$ had increased while the Chinese [19] (9 mm) had diminished STCT. The superior sulcus depth in all populations was within the HA established value apart from the Chinese [19] (9 $\mathrm{mm}$ ), who revealed increased value. Moreover, the $\mathrm{SN}-\mathrm{H}$ line for all populations was within the normal HA established value apart from the Japanese [20] $(9.06 \mathrm{~mm})$, which revealed increased value. The ULT for all populations was within the HA established value apart from the Palestinians [32] (12.33 mm) who revealed diminished value. The $\mathrm{H}$ angle for all populations was increased when compared with the HA established value apart from the Palestinians [32] (14.21 degrees), which was within the HA established value. Finally, the LL$\mathrm{H}$ line for all populations was within the HA established value.

Wei [33] has established no remarkable gender dimorphism in angular measurements, also a more similar craniofacial method in both genders of Chinese subjects. The male profile has remained more or less larger in overall linear measurements. Cheng [34], in his investigation of Malaysian genders, found no major differentiation in angular measurements, though the linear measurements have remained smaller for females when compared to males. In the current study, simply the ULT (vermillion UL-A point) has demonstrated a significant difference $(\mathrm{p}<0.05)$. The current study has shown the Class I classification of soft tissue measurements. Burstone [7] has reported that lip lengths in normal adolescent girls have remained more than $3 \mathrm{~mm}$ lesser for upper lip (UL) and lower lip (LL) when compared to young men, which have suggested lip retrusion in normal adolescent girls. In this study, females lip lengths were also not nearly to the males. The length of the male nose in Malaysian Chinese population [23] has remained more prominent, yet the nose angles were pretty equivalent among the two genders. The current study also revealed comparable results with no significant difference. Malaysian Indian [25] also demonstrated a significant difference in nose prominence. Malaysian Chinese [23] and Malaysian Indians [25] chin tip were significantly greater in males. This was a measurement of the anteroposterior prominence of the combined size and position of lower jaw covering the soft tissue. Yeong and Huggare [35], who measured the Singaporean Chinese population, have stated that adolescent females presented more prominent mandibular prognathism than adolescent men among which the growth spurt would have occurred.

In this study, lip morphology (LM) was also measured using cephalometric linear and angular analyses by reference to Steiner's S line [12] and Ricketts E-line [11]. LM measurements were also compared with Malaysian Chinese [23], Malaysian Malay [24], Nigerian [36], North Indian [26] and Pakistani [27] populations (Table 6). Every single other population utilized cephalometry as their study tool. Considering Ls to $\mathrm{E}$ line, the Malaysians $(-1.03 \mathrm{~mm}$ and $-0.015 \mathrm{~mm})$ got negative values, which have specified that the UL was positioned in front of the $\mathrm{E}$ line. The Nigerians [36] got a larger distance considering Ls to $\mathrm{E}$ line and Li to $\mathrm{E}$ line. The lower lip (LL) got a larger distance to E line than the upper lip (UL), which demonstrated that they got retrusive lips. Considering $\mathrm{Li}$ to $\mathrm{E}$ line, negative values have also demonstrated that the LL was positioned 
in front of the $\mathrm{E}$ line. The outcome for the Pakistani [27] (-0.715 mm) population was parallel to the current study $(-0.24 \mathrm{~mm})$, where $\mathrm{Li}$ to $\mathrm{E}$ line has shown negative values for both populations. Li to E line values were positive for the Malaysians [23,24] and the Nigerians [36]. Nigerians [36] have got quite larger distance among LL and the $\mathrm{E}$ line. The nasolabial angle (NA) in the current study was relatively similar to the Pakistani population [27]. The Malaysian Malays [24] $\left(84.89^{\circ}\right)$ had the smallest NA, while the North Indians [26] $\left(112.14^{\circ}\right)$ had the largest. The inferior labial sulcus angle (ILSA) was the least in the Pakistani [27] $\left(104.1^{\circ}\right)$ population and the most in the Malaysian Chinese [23] $\left(144.48^{\circ}\right)$. The smaller ILSA in the Pakistani population [27] has demonstrated that they got a prominent chin. The consequence of the ILSA in the current study $\left(133.22^{\circ}\right)$ was pretty similar to the North Indian [26] $\left(128.8^{\circ}\right)$ population.

The ULP was the most elevated in the Nigerian [36] $\left(6.77^{\circ}\right)$ population and the least in the Malaysian Malays [24] $\left(1.24^{\circ}\right)$. The current study and the Nigerians [36] have revealed a small ULP angle. However, the ULP angle in the Malaysian Malays [24] and the Pakistanis [27] have remained pretty higher when compared with their ULP. The lower lip protrusion (LLP) was the largest in the Nigerian [36] (9.02 $\left.{ }^{\circ}\right)$ population and the smallest in the Malaysian Malays [24] $\left(1.67^{\circ}\right)$. The LLP angle in the current study and the Nigerians [36] have revealed that they got low LLP angle. Once again, the LLP angle in the Pakistani population [27] was higher than their LLP. Soft tissue measurements in the Japanese subjects [37] have revealed the ULP of $6.4 \pm 1.6 \mathrm{~mm}$ in males and $6.5 \pm 1.5 \mathrm{~mm}$ in females. In the current study, the ULP was $5.22 \mathrm{~mm}$ in males and $5.06 \mathrm{~mm}$ in females, demonstrating that the Bangladeshi subjects had little retruded UL compared with the Japanese [37]. LLP was $4.33 \mathrm{~mm}$ in males and $4.31 \mathrm{~mm}$ in females, which was nearly comparable to the Japanese [37].

In orthodontic soft tissue analysis and treatment, the relationship of the lips to the subnasalepogonion (SnP) line is considered as a fundamental guide. Development of the tooth changes the relationship of the lips to the SnP line and that may influence the visual outcome. Measurements of the lips through Steiner's S line [12] and Ricketts E-line [11] deal with the relations of chin, lips and nose. Alcalde et al. [20] has presented that the UL and LL of the Japanese were anteriorly situated in all studies.

NA is significantly affected by orthodontics and surgical procedures. In the current study, this angle has revealed no gender dimorphism. The ILSA was marginally bigger in males when compared to the females. Ioi et al. [37] similarly has established that female had smaller ILSA than males. The UL of the Malaysian Indian females has remained further protrusive, yet the LL has remained retrusive when compared with the $\mathrm{E}$ line [25]. Purmal et al. [23] has revealed in another study of Malaysian Chinese, that lips have remained more protrusive in females than males. Cheng [34] has indicated in his study that soft tissue morphology is affected by alveolar prognathism and thickness of the soft tissue profile. Lew et al. [19] has mentioned, this protrusion may appear misrepresented because the chin and nose have remained less prominent. NA was observed to be more acute in males when compared to the females [25]. This result has revealed as per the present study.

\section{Conclusion}

3D CT soft tissue norms have been established for Bangladeshi adults using HA and LM analyses. Overall, the results of the current study equally accept the concept that every ethnic group has its standards depending on anthropological and morphological findings.

Regarding this study, there are few varieties in the soft tissue facial structure of the Bangladeshi normal subjects. These varieties ought to be thought-about to assure better diagnosis and treatment planning of the Bangladeshi subjects, especially during orthognathic surgery and orthodontic treatment planning. 
Moreover, 3D digitization can be used together in clinical practice and research fields as it was proven to be precise and sensitive in obtaining the data.

\section{Authors' Contributions \\ MI (iD https://orcid.org/0000-0002-1160-7719 Conceptualization, Methodology, Formal Analysis, Investigation, Writing - Original Draft and MKA (D) https://orcid.org/0000-0001-7131-1752 Writing - Review and Editing. \\ Conceptualization, Methodology, Formal Analysis, Investigation, Writing - Original Draft and \\ AY (D) https://orcid.org/o0oo-0001-7731-2123 Conceptualization, Methodology, Formal Analysis, Investigation, Writing - Original Draft and Writing - Review and Editing. \\ All authors declare that they contributed to critical review of intellectual content and approval of the final version to be published.}

\section{Financial Support}

None.

\section{Conflict of Interest}

The authors declare no conflicts of interest.

\section{Data Availability}

The data used to support the findings of this study can be made available upon request to the corresponding author.

\section{References}

[1] Hershon LE, Giddon DB. Determinants of facial profile self-perception. Am J Orthod 1980; 78(3):279-95. https://doi.org/10.1016/0002-9416(80)90273-0

[2] Peck S, Peck L. Selected aspects of the art and science of facial esthetics. Semin Orthod 1995; 1(2):105-26. https://doi.org/10.1016/s1073-8746(95)80097-2

[3] Durer A. The Art of Measurement. San Francisco: Alan Wofsy Fine Arts, 1981.

[4] Sahin Sağlam AM, Gazilerli U. Analysis of Holdaway soft-tissue measurements in children between 9 and 12 years of age. Eur J Orthod 2001; 23(3):287-94. https://doi.org/10.1093/ejo/23.3.287

[5] Bishara SE, Cummins DM, Jakobsen JR, Zaher AR. Dentofacial and soft tissue changes in Class II, division 1 cases treated with and without extractions. Am J Orthod Dentofacial Orthop 1995; 107(1):28-37. https://doi.org/10.1016/s0889-5406(95)70154-O

[6] Farkas LG, Kolar JC. Anthropometrics and art in the aesthetics of women's faces. Clin Plast Surg 1987; 14(4):599616.

[7] Burstone CJ. Lip posture and its significance in treatment planning. Am J Orthod 1967; 53(4):262-84. https://doi.org/10.1016/0002-9416(67)90022-x

[8] Holdaway RA. A soft-tissue cephalometric analysis and its use in orthodontic treatment planning. Part I. Am J Orthod 1983; 84(1):1-28. https://doi.org/10.1016/0002-9416(83)90144-6

[9] Holdaway RA. A soft-tissue cephalometric analysis and its use in orthodontic treatment planning. Part II. Am J Orthod 1984; 85(4):279-93. https://doi.org/10.1016/0002-9416(84)90185-4

[10] Angelle PL. A cephalometric study of the soft tissue changes during and after orthodontic treatment. Trans Eur Orthod Soc 1973; 267-80.

[11] Ricketts RM. Esthetics, environment, and the law of lip relation. Am J Orthod 1968; 54(4):272-89. https://doi.org/10.1016/s0002-9416(68)90278-9

[12] Steiner CC. Cephalometrics for you and me. Am J Orthod 1953; 39(10):729-755. https://doi.org/10.1016/o0029416(53)90082-7

[13] Broadbent BH. A new x-ray technique and its application to orthodontia. Angle Orthod 1931; 1(2):45-66. https://doi.org/10.1043/0003-32 19(1931)001<0045:ANXTAI>2.0.CO;2

[14] Major PW, Johnson DE, Hesse KL, Glover KE. Landmark identification error in posterior anterior cephalometrics. Angle Orthod 1994; 64(6):447-54.

[15] Pauwels R, Beinsberger J, Collaert B, Theodorakou C, Rogers J, Walker A, et al. Effective dose range for dental cone beam computed tomography scanners. Eur J Radiol 2012; 81(2):267-71. https://doi.org/10.1016/j.ejrad.2010.11.028

[16] Baik HS, Jeon JM, Lee HJ. Facial soft-tissue analysis of Korean adults with normal occlusion using a 3-dimensional laser scanner. Am J Orthod Dentofacial Orthop 2007; 131(6):759-66. https://doi.org/10.1016/j.ajodo.2005.08.038

[17] Mandall NA, McCord JF, Blinkhorn AS, Worthington HV, O'Brien KD. Perceived aesthetic impact of malocclusion and oral self-perceptions in 14-15-year-old Asian and Caucasian children in greater Manchester. Eur J Orthod 2000; 22(2):175-83. https://doi.org/10.1093/ejo/22.2.175 
[18] Zylinski CG, Nanda RS, Kapila S. Analysis of soft tissue facial profile in white males. Am J Orthod Dentofacial Orthop 1992; 101(6):514-8. https://doi.org/10.1016/0889-5406(92)70125-T

[19] Lew KK, Ho KK, Keng SB, Ho KH. Soft-tissue cephalometric norms in Chinese adults with esthetic facial profiles. J Oral Maxillofac Surg 1992; 50(1 1):1184-9. https://doi.org/10.1016/0278-2391(92)90151-o

[20] Alcalde RE, Jinno T, Orsini MG, Sasaki A, Sugiyama RM, Matsumura T. Soft tissue cephalometric norms in Japanese adults. Am J Orthod Dentofacial Orthop 2000; 118(1):84-9. https://doi.org/10.1067/mod.2000.104411

[21] Park IC, Bowman D, Klapper L. A cephalometric study of Korean adults. Am J Orthod Dentofacial Orthop 1989; 96(1):54-9. https://doi.org/10.1016/0889-5406(89)90229-1

[22] Siddika A, Rahman SA, Alam MK. Ricketts' cephalometric analysis for Saudi population. Pesqui Bras Odontopediatria Clín Integr 2020; 20:e5364. https://doi.org/10.1590/pboci.2020.059

[23] Pumal K, Alam MK, Mohammad N, Zam Z. Cephalometric Norms of Malaysian Adult Chinese. Int Med J 2013; 20(1):87-91.

[24] Talib MA, Aziz NSA, Alam MK, Basri R. Linear and Angular Cephalometric Measurement of Lip Morphology among Malaysian Malay. Int Med J 1994; 2 1(1):41-4.

[25] Pumal K, Alam MK, Zam Zam NM. Cephalometric Norms of Malaysian Adult Indian. Int Med J 2013; 20(2):192-196.

[26] Mittal A, Garg R, Gupta SK. "Are we similar to Caucasians"- Orthognathic surgery for North Indians. Int J Dent Sci Res 2014; 2(4):80-6. https://doi.org/10.12691/ijdsr-2-4-3

[27] Khan F, Mahroof V, Kamran AK, Shafiqullah, Allam MK, Qamruddin I. Cephalometric lip morphology in a sample from Pakistani population. Int Med J 2017; 24(1):140-3.

[28] Alam MK, Basri R, Purmal K, Sikder MA, Saifuddin M, Lida J. Soft tissue cephalometric analysis for Bangladeshi adult using Holdway's analysis. Int Med J 2012; 19(4):333-6.

[29] Alam MK, Basri R, Purmal K, Sikder MA, Saifuddin M, Lida J. Cephalometric lip morphology in Bangladeshi population. Int Med J 2013; 20(2):201-203.

[30] Bayome M, Park JH, Kook YA. New three-dimensional cephalometric analyses among adults with a skeletal Class I pattern and normal occlusion. Korean J Orthod 2013; 43(2):62-73. https://doi.org/10.4041/kjod.2013.43.2.62

[31] Albarajati SF, Bindayel NA. Holdaway soft tissue cephalometric standards for Saudi adults. King Saud University J Dent Sci 2012; 3(1):27-32. https://doi.org/10.1016/j.ksujds.2011.10.004

[32] Hussein E, Al Khateeb S, Watted N, Aksoy A, Acar A, Mowais MA. Evaluation of facial soft tissue parameters for Palestinians using Holdaway analysis. Saudi Dent J 2011; 23(4):191-5. https://doi.org/10.1016/j.sdentj.201 1.08.003

[33] Wei SH. A roentgenographic cephalometric study of prognathism in Chinese males and females. Angle Orthod 1968; 38(4):305-20.

[34] Cheng FG. A cephalometric study of the Chinese in profile. Aust Orthod J 1986; 9(3):285-8.

[35] Yeong P, Huggare J. Morphology of Singapore chinese. Eur J Orthod 2004; 26(6):605-12. https://doi.org/10.1093/ejo/26.6.60

[36] Ikenna Isiekwe G, Olatokunbo Da Costa O, Chukwudi Isiekwe M. A cephalometric investigation of horizontal lip position in adult Nigerians. J Orthod 2012; 39(3):160-9. https://doi.org/10.1179/1465312512Z.00000000026

[37] Ioi H, Nakata S, Nakasima A, Counts AL. Anteroposterior lip positions of the most-favored Japanese facial profiles. Am J Orthod Dentofacial Orthop 2005; 128(2):206-11. https://doi.org/10.1016/j.ajodo.2004.04.030 